Check for updates

Cite this: RSC Adv., 2018, 8, 18635

\title{
Mad honey: uses, intoxicating/poisoning effects, diagnosis, and treatment
}

\author{
Sana Ullah, (D) a Shahid Ullah Khan, (D) *b Tawfik A. Saleh (D)*c and Shah Fahad ${ }^{\text {bd }}$
}

Honey has been used as a folk medicine since 2100 BC; however, mad honey is different from normal natural or commercially available honey as it is contaminated with grayanotoxins, which leads to intoxication/poisoning upon consumption. Grayanotoxin is generally found in Rhododendron genus (family: Ericaceae) and is extracted by bees from nectar and pollens of flowers. Mad honey has been commonly used as an aphrodisiac (sexual stimulant), in alternative therapy for gastrointestinal disorders (peptic ulcer disease, dyspepsia, and gastritis), and for hypertension for a long time. Grayanotoxin acts on sodium ion channels and muscarinic receptors, leading to cardiac disorders (hypotension and different rhythm disorders including bradycardia, bradydysrhythmias, atrial fibrillation, nodal rhythm, atrioventricular block, and complete atrioventricular block) and respiratory depression. Patients may also exhibit any one symptom out of or combination of dizziness, blurred vision, diplopia, nausea, vomiting, vertigo, headache, sweating/excessive perspiration, extremity paresthesia, impaired consciousness, convulsion, hypersalivation, ataxia, inability to stand, and general weakness. Mad honey intoxication is diagnosed with honey intake history before the appearance of the signs and symptoms (clinical presentation), and the treatment is symptomatic. Prompt treatment includes intravenous infusions of atropine sulfate and fluids (saline infusions or simultaneous infusion of saline with atropine sulfate) if the patient presents bradycardia and severe hypotension. In case of a complete atrioventricular block, a temporary pacemaker is employed. Except for a single case from Lanping County (Southwest China), the prognosis for mad honey intoxication is very good, and no fatalities have been reported in modern medical literature excluding a few in the 1800s. Although fatalities are very rare, mad honey ingestion may still lead to arrhythmias, which can be life-threatening and hard to recognize. This article provides a brief introduction to honey, mad honey and its uses, the effects of mad honey intoxication/poisoning, and its diagnosis, prognosis, and treatment.

rsc.li/rsc-advances

\section{Introduction}

\section{Honey}

Honey is a complex natural food produced from plants' nectar and honeydew by bees, and it can be consumed without processing. It has varying compositions depending on the species of the honeybees, honeydew sources, flora and their origin, geographic region, climate, weather, manipulation, processing, packaging, and time of the storage, and it is mainly composed of sugars and other substances, i.e., minerals, vitamins, proteins, organic acids, aromatic acids, and waxes. ${ }^{1}$ The use of honey as a folk medicine can be dated back to $2100 \mathrm{BC}$, and it has been used for colds, wound healing, diabetes, sexual

${ }^{a}$ School of Life Sciences, Nanjing University, Nanjing, Jiangsu 210023, P. R. China ${ }^{b}$ College of Plant Sciences and Technology, National Key Laboratory of Crop Genetics Improvement, Huazhong Agricultural University, Wuhan, People's Republic of China. E-mail: shahidbiochem@webmail.hzau.edu.cn

${ }^{c}$ Department of Chemistry, King Fahd University of Petroleum \& Minerals, Dhahran, Saudi Arabia.E-mail: tawfikas@hotmail.com

${ }^{d}$ Department of Agriculture, University of Swabi, Swabi, Pakistan stimulation, hypertension, diabetes, ulcers, and gastritis. ${ }^{2-5}$ Honey is a remarkable liquid containing at least 181 substances. ${ }^{64}$ Table 1 shows the average composition of reference source honey. ${ }^{6,7}$

Recent research on honey has revealed its different biological activities. The potential health benefits of honey include its anti-tumor, ${ }^{8,9}$ anti-inflammatory, ${ }^{\mathbf{1 0 , 1 1}}$ anti-microbial (such as anti-fungal, ${ }^{12,127}$ anti-viral, ${ }^{13-15}$ and anti-bacterial ${ }^{16-19}$ ), antitussive ${ }^{20}$ cardio-protective,${ }^{21}$ hepato-protective ${ }^{22}$ anti-diabetic, ${ }^{23,24}$ anti-oxidant, ${ }^{\mathbf{9 , 1 1 , 2 5 , 2 6}}$ and anti-hypertensive ${ }^{27}$ effects. Fig. 1 shows some biological uses and effects of honey.

Consumption of honey containing toxins can lead to poisoning/intoxication. There are two types of honey intoxication/poisoning. Consumption of honey containing grayanotoxins (from Rhododendron species of plants) is termed as mad honey poisoning, and it is mostly reported in Turkey, Korea, and Nepal, whereas the consumption of honey containing tutin (a neurotoxin from Coraria species of shrubs) is termed tutin honey poisoning, and it has been reported in New Zealand..$^{36,67,131-134}$ 
Table 1 Average composition of reference source honey

\begin{tabular}{lll}
\hline S. no. & Components & $\begin{array}{l}\text { Value per 100 } \\
\text { gram honey }\end{array}$ \\
\hline 1 & Total carbohydrates & $82.4 \mathrm{~g}$ \\
2 & Glucose & $31.28 \mathrm{~g}$ \\
3 & Maltose & $7.31 \mathrm{~g}$ \\
4 & Fructose & $38.5 \mathrm{~g}$ \\
5 & Sucrose & $1.31 \mathrm{~g}$ \\
6 & Amino acids & $0.3 \mathrm{~g}$ \\
7 & Total acids & $0.57 \mathrm{~g}$ \\
8 & Moisture content & $17.1 \mathrm{~g}$ \\
9 & Nitrogen & $0.041 \mathrm{~g}$ \\
10 & Ash & $0.169 \mathrm{~g}$ \\
11 & Calcium & $6.00 \mathrm{mg}$ \\
12 & Phosphorous & $4.00 \mathrm{mg}$ \\
13 & Potassium & $52 \mathrm{mg}$ \\
14 & Iron & $0.42 \mathrm{mg}$ \\
15 & Magnesium & $2.00 \mathrm{mg}$
\end{tabular}

\section{Mad honey}

Mad honey is different from commercial/marketed honey as it is contaminated with grayanotoxin; it is known as mad honey due to its intoxicating/poisoning effects. ${ }^{28,29}$ Grayanotoxins are diterpenes, polyhydroxylated cyclic hydrocarbons, containing no nitrogens. ${ }^{30}$ Grayanotoxins cause intoxication and are extracted by honey bees from the nectar and pollen of the plants of the Rhododendron genus (Ericaceae family), most commonly from $R$. luteum, $R$. flavum, $R$. simsii, and $R$. ponticum. Therefore, grayanotoxins are also known as rhodotoxins. ${ }^{31,32,132}$ Other names used for grayanotoxins are acetylandromedols or andromedotoxins. ${ }^{33}$ The toxins from Tripterygium hypoglaucum (Celastraceae family) are reported to be highly toxic, and consumption of honey contaminated with pollen from
T. hypoglaucum led to the death of $25.8 \%$ (8/31) of patients (2007-2012) in southwestern China. ${ }^{\mathbf{1 3 2}}$ Mad honey intoxication has been reported in many countries around the globe including Turkey, China, Philippines, Korea, Indonesia, Japan, Nepal, Austria, Germany, Brazil, and some countries of North America, ${ }^{31,34-48,132}$ but most of the cases are reported from Asia minor and Turkey (Fig. 2). According to Salici and Atayoglu, ${ }^{29} 69$ out of 84 articles published on mad honey intoxication/ poisoning were published by Turkish researchers, covering 1199 cases. Honey containing grayanotoxin is even more toxic during spring as compared to mad honey produced in other seasons. ${ }^{41}$ Mad honey has a bitter sharp taste, and it irritates the throat; therefore, it is also known as bitter honey. ${ }^{49-51}$

\section{Uses of mad honey}

Mad honey is employed for various purposes, which are different from those of regular honey. It is used as an alternative medicine used for hypertension, diabetes (hyperglycaemia and related complications), flu, gastrointestinal disorders (peptic ulcers, gastritis, dyspepsia, indigestion, bowel disorders, and other discomforts), abdominal/gastric pain, arthritis, stimulating sex (dysfunction, impotence, enhancement, and performance), various viral infections, skin ailments, pain, and cold. ${ }^{29,41,43,47,50,52-56,132}$ The antiradical bioactivities, such as antidiabetic, anti-inflammatory, antioxidant, analgesic, antimicrobial, cytotoxic, and insecticidal, of Rhododendron species are also well established. ${ }^{53,57-63}$ Silici et $a l .{ }^{64}$ reported chlorogenic, coumaric, ferulic, and gallic acids to be the main phenols in mad honey. Silici and Karaman ${ }^{65}$ reported arginine, lysine, and aspartic acid to be the main amino acids in mad honey. Buratti et al. ${ }^{66}$ reported that mad honey has the highest level of antioxidant activity among other types of honey. Mad honey is also used as a weapon..$^{69,84,135,136}$

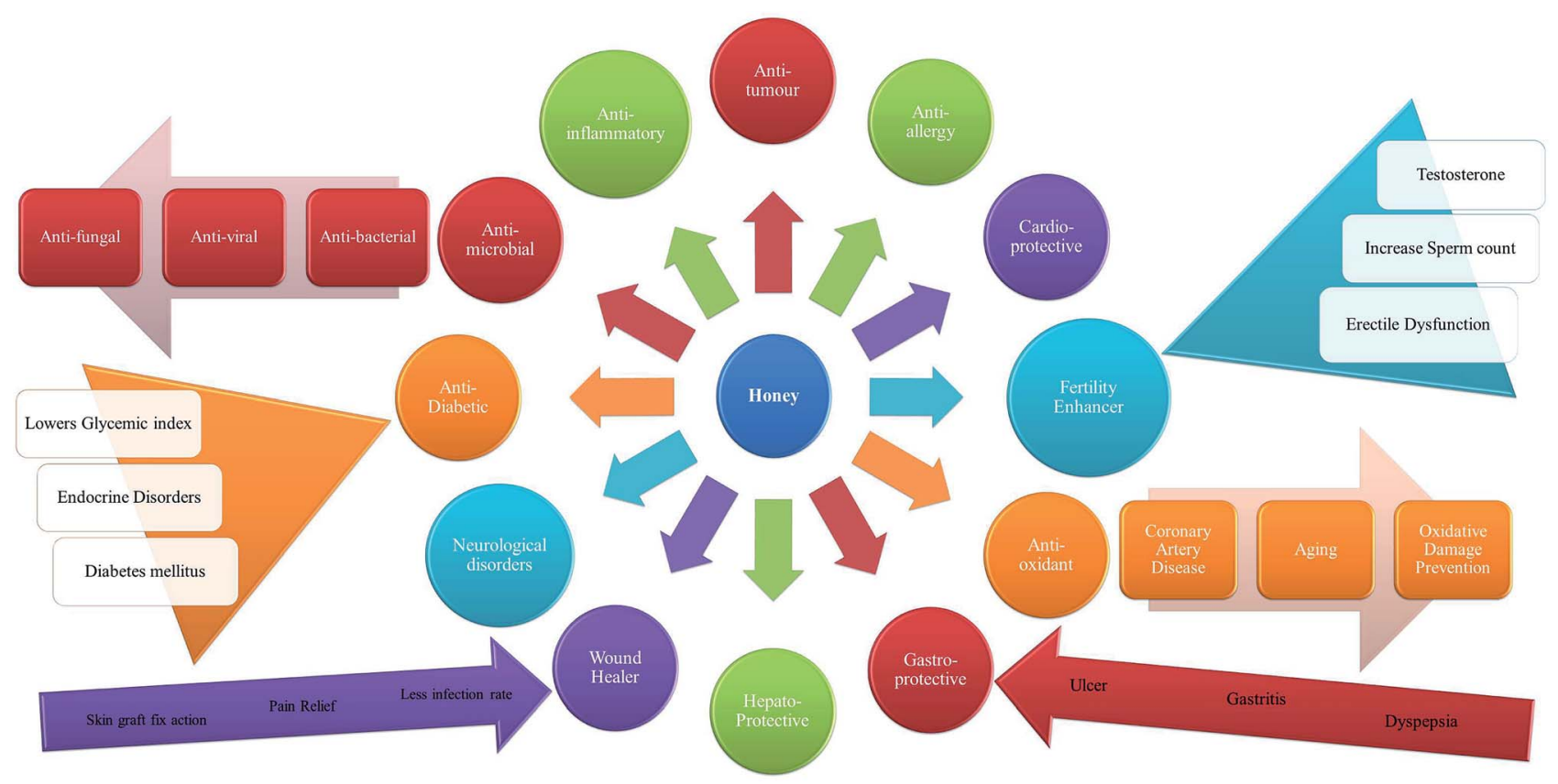

Fig. 1 Some uses and biological effects of honey. 

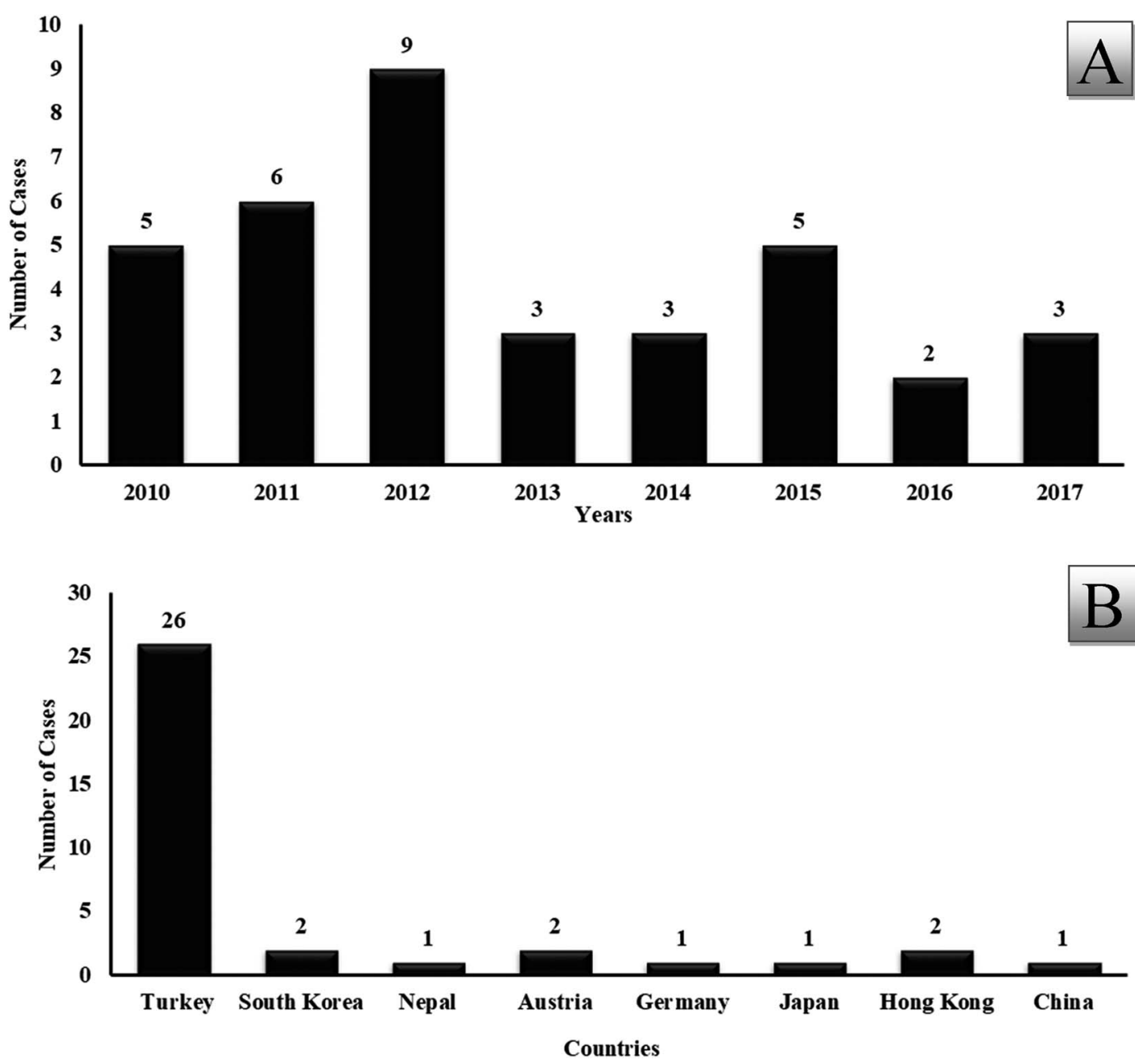

Fig. 2 Reported cases per year (A) and reported cases from different countries (B) since 2010 (total cases = 36) - searched in PubMed, Scopus, and Science direct.

The use of mad honey as an aphrodisiac is more common and continuously rising, suggesting its popularity and global demand. According to a report, South Korea alone imported over $8000 \mathrm{~kg}$ of mad honey from Nepal during 2003-04 and then, further import was banned by the Korean government in $2005 .{ }^{67}$ However, mad honey intoxication cases have been reported even after its ban in South Korea, because of illegal imports and direct purchase by Korean travelers in Nepal. ${ }^{45} \mathrm{Mad}$ honey is mostly used by middle-aged men for enhancing their sexual performance. ${ }^{53}$ Commercial honey is safer to consume but in case of contamination, the mass yield and production of honey dilute the quantities of toxins. Mad honey intoxication has been reported from different countries around the globe, and the origin can be traced back to the Black Sea region of Turkey or Nepal. ${ }^{45,67-69}$ Table 2 shows recently (2010 onward) reported cases of mad honey intoxication/poisoning, evidencing that mad honey is still widely consumed.

\section{Poisoning/intoxicating effects of mad honey}

Mad honey poisoning was reported by Xenophon (an Athenian military commander and author) for the first time in 401 BC. ${ }^{\mathbf{1 2 8}}$
Moreover, mad honey was used by King Mithradates IV (Northeast Anatolia, Turkey) as a weapon in 67 BC against Pompey the great. ${ }^{129}$ Although mad honey poisoning is not a classical cholinergic toxidrome, it does possess cholinergic toxicity and affects cardiovascular systems..$^{28,70}$ The signs and symptoms can be seemingly life-threatening but are very rarely fatal. Table 3 shows the reported effects/complaints of mad honey intoxication/poisoning by the patients. A case study series from Southeast China (Lanping County) reported the deaths of 8 out of 31 patients $(25.8 \%)$ upon consumption of honey contaminated with pollen from T. hypoglaucum..$^{\mathbf{1 3 1}}$ A very brief description of the frequently reported toxic effects of mad honey is provided herein.

The toxins act on sodium ion channels at the cellular level and modify their functions by interfering in the action potential transmission and blocking the sodium channels, causing inotropy. ${ }^{\mathbf{4 0 , 7 0}}$ Grayanotoxin attaches to the voltage-dependent sodium channels in their open state within excitable cells, including muscles and nerves, and modifies them. ${ }^{39,51,71}$ The receptor contains S6 transmembrane segments having four homologous domains facing toward ion-conducting pores. ${ }^{72}$ The binding and access of the toxin to the receptors are 
Table 2 Case reports in various countries regarding mad honey intoxication/poisoning reported since 2010

\begin{tabular}{lll}
\hline S. no. & Case reports/references & Country \\
\hline 1 & 90 & South Korea \\
2 & 45 & South Korea \\
3 & 47 & Nepal \\
4 & 113 & Turkey \\
5 & 51 & Turkey \\
6 & 110 & Turkey \\
7 & 89 & Turkey \\
8 & 114 & Turkey \\
9 & 115 & Turkey \\
10 & 116 & Turkey \\
11 & 117 & Turkey \\
12 & 118 & Turkey \\
13 & 43 & Turkey \\
14 & 119 & Turkey \\
15 & 120 & Turkey \\
16 & 121 & Turkey \\
17 & 111 & Turkey \\
18 & 55 & Turkey \\
19 & 122 & Turkey \\
20 & 70 & Turkey \\
21 & 63 & Turkey \\
22 & 123 & Turkey \\
23 & 28 & Turkey \\
24 & 124 & Turkey \\
25 & 125 & Turkey \\
26 & 41 & Turkey \\
27 & 40 & Turkey \\
28 & 87 & Turkey \\
29 & 75 & Turkey \\
30 & 31 & Austria \\
31 & 39 & Austria \\
32 & 42 & Germany \\
33 & 46 & Japan \\
34 & Hong Kong \\
35 & 48 & Hong Kong \\
36 & & China \\
& &
\end{tabular}

regulated by phenylalanine (Phe) and tyrosine (Tyr) residues, facilitating affinity of grayanotoxin to the sodium channels. ${ }^{72}$ Grayanotoxin binds with the sodium channel, prevents its inactivation, elevates its membrane permeability, inhibits its repolarization, and moves the membrane potential in hyperpolarization direction; ${ }^{28,72,132}$ the toxin ultimately prolongs depolarization and behaves like a cholinergic agent, resulting in bradycardia, hypotension, and depression of respiratory rate. ${ }^{28,32,72,73}$ The sinus node dysfunction is caused by the decreased action potential. ${ }^{74,75}$ The sodium channels of the skeletal muscles are more sensitive to grayanotoxin than those of the cardiac muscles. ${ }^{76}$ The observed responses of the nerves, muscles (skeletal and heart), and central nervous system are all linked to these membrane effects. ${ }^{50}$

Muscarinic effects of grayanotoxin have also been reported. A study revealed that due to grayanotoxin, atropine reversed both respiratory depression and bradycardia, whereas a selective M2 (muscarinic-2) receptor antagonist, AFX-DX 116, reversed bradycardia only. ${ }^{54}$ This suggests the mediating effect of grayanotoxin through the M2 receptor (having no respiratory effect), which leads to bradycardia, consequently inducing cardiotoxicity. ${ }^{77,78}$ Smaller doses of toxins are required for respiratory depression and bradycardia at the same level when injected intraventricularly as compared to those injected intraperitoneally, which suggests the central nervous system as the site of action for respiratory and cardiac effects. After bilateral vagotomy, no bradycardia is observed, suggesting the involvement of vagal pathways..$^{55,77,79}$

Grayanotoxin has different types, and each type has its own effect. There are 18 known grayanotoxin forms; ${ }^{132}$ however, not all of them lead to poisoning/intoxication/toxic effects. ${ }^{35}$ Grayanotoxin I is reported to be accountable for cardiac manifestations, affecting both atrioventricular conduction and the sinoatrial node. ${ }^{70,80}$ Grayanotoxin II is less toxic as compared to grayanotoxin I and grayanotoxin III, and it leads to suppression of the natural beating of the sinoatrial node; grayanotoxin II inhibits electrical activity of the sinoatrial node cells via elevating permeability of the membrane to sodium ions and consequently hyperpolarizing cells, ultimately inactivating slow inward currents, followed by a reduction in activation of outward currents. ${ }^{81}$ Grayanotoxin III leads to arrhythmia. Omotayo et al. ${ }^{25,27}$ observed that grayanotoxin III administration leads to repetitive or amplitude supra-threshold after-potentials within fifteen minutes in feline cardiac Purkinje fibers. The triggered activity is augmented, and grayanotoxin III production-induced after-potentials are enhanced by an increase in the stimulation frequency, increase in calcium concentration in the extracellular domain or decrease in extracellular potassium concentration. Conversely, increasing concentration of extracellular potassium or verapamil (a calcium channel blocker) blocks the triggered activity and represses grayanotoxin III-elicited after-potentials. An increase in calcium influx is obtained through the voltage-dependent calcium channels, which is secondary to the voltagedependent sodium channel activation in excitatory and inhibitory nerve terminals. ${ }^{82}$ Thus, arrhythmias induced by grayanotoxin III are due to the triggered activity in oscillatory form after potential. ${ }^{83,126}$ However, none of the patients intoxicated with grayanotoxin III died, and they recovered at the same hour next day and completely recovered after treatment after three to four days. $^{84}$

Grayanotoxin metabolism and excretion take place within 24 hours and thus, the symptoms last no more than a day. ${ }^{85}$ There is a linear relation between toxic effects and the amount of mad honey ingested; however, the distribution of grayanotoxin is not homogenous within honey and leads to different intoxication levels in different patients..$^{38,40,41,55,85}$ The majority of reports are for males aged between 40-60 years..$^{29,53}$ The higher prevalence in this age group is due to the higher use of mad honey as a sexual stimulant as well as a higher rate of hypertension. ${ }^{53}$ Consumption of about 15-30 g mad honey leads to intoxication, and symptoms appear after half to $4 h^{.30,41,70,75,85-87}$ The level of intoxication not only depends on the amount of mad honey consumed but also on the grayanotoxin concentration in the honey and the season of production. ${ }^{32}$ According to Ozhan et al.,$^{85}$ consumption of one teaspoon of mad honey may lead to poisoning. The severity and course of clinical symptoms vary 
Table 3 The reported effects/complaints of mad honey intoxication/ poisoning

\begin{tabular}{llll}
\hline & & & $\begin{array}{l}\text { Complaints/ } \\
\text { S. no. }\end{array}$ \\
\hline 1 & Complaints/reported effects & S. no. & reported effects \\
3 & Bradycardia & 2 & Hypotension \\
5 & Syncope & 4 & Fainting \\
7 & Vomiting & 6 & Nausea \\
9 & Presyncope & 8 & Dizziness \\
11 & Chest pain & 10 & Vertigo/headache \\
13 & Sweating & 12 & Impaired consciousness \\
15 & Cramp & 14 & Hypersalivation \\
17 & Gastroenteritis & 16 & Chills \\
19 & Cyanosis & 18 & Collapse \\
21 & Diaphoresis & 20 & Ataxia \\
23 & Diarrhoea & 22 & Mental confusion \\
25 & Paraesthesia & 24 & Palpitation \\
27 & Cold sweating & 26 & Diplopia \\
29 & Light headedness & 28 & Dyspnoea \\
31 & Colic & 30 & Malaise \\
33 & Excessive perspiration & 32 & Agitation \\
35 & Coma & 34 & Cramp \\
37 & Blurred vision & 36 & Exhaustion \\
39 & Hyperthermia (malaria-like) & 48 & Tachycardia \\
41 & Progressive muscular & 42 & Dysphagia \\
& weakness & & \\
43 & Unconsciousness & 44 & Fatigue \\
& & &
\end{tabular}

with the sensitivity of the consumers to the toxin. Notably, symptoms including vomiting, nausea, nodal rhythms, and second-degree heart block are less severe and less frequent in females as compared to those in males. ${ }^{45,53,86,88-90}$ Akca and Kahveci $^{70}$ reported that men suffer 5 times more incidences of mad honey poisoning/intoxication as compared to women. However, long term consumption may lead to desensitization of $\mathrm{Na}^{+}$channels in the excitable cells, which precludes intense symptomatic presentation itself. ${ }^{38}$

A number of hospitalized cases of mad honey intoxication have been reported, and most of them are due to cardiac manifestations of grayanotoxin (Table 4 - case reports of more than 2 patients and those reported after 2004). Bradycardia and hypotension are the most common physical findings, and other findings and accompanying symptoms are associated with these two findings generally. ${ }^{36,50,75}$ These two symptoms are as frequent as $90 \%$ in all the reported cases. $^{36,55,75}$ The afferent cardiac branches in the vagus nerves are stimulated, leading to tonic inhibition of the vasomotor centers, followed by reduction of sympathetic output, which ultimately causes bradycardia, hypotension, and peripheral vasodilation. ${ }^{86,91,136}$ The patient might present chest heaviness or tightness and ST changes such as an increase in ST on ECG, imitating acute coronary syndromes. This is attributed to bradycardia and hypotension, resulting in a reduced supply of blood to the coronary artery bed, which in turn leads to reduced supply of oxygen to the myocardium. Yarlioglues et al. ${ }^{63}$ Akinci et al. ${ }^{92}$ and Yildirim et al.$^{93}$ have reported mad honey-mediated myocardial infarction/ischemia.

Arrhythmias such as atrioventricular block, nodal rhythms and more commonly sinus bradycardia can also be observed, which might be due to direct stimulation of the fibers of afferent vagal nerves causing tonic inhibition of vasomotor centre, which leads to vagal inhibition of the function of sinus node and decreased sympathetic output. . $^{40,42,74,77,91,94}$ According to Eller and Hochegger ${ }^{39}$ the grayanotoxins cardio-inhibit the Bezold-Jarisch reflex, which leads to bradycardia, peripheral vasodilation, and continued hypotension. Bradycardia mediated by M2 might be another possible mechanism. The severity of bradycardia is dependent on dose/concentration of grayanotoxin consumed. ${ }^{55}$

Sinus bradycardia, nodal rhythms, and varying degrees of atrioventricular block are the most common cardiac rhythm disorders reported in mad honey intoxication/poisoning. ${ }^{75,95}$ Different symptoms including hypothermia, heart block (seconddegree), blocked left bundle branch (extreme QT prolongation), atrial fibrillation, asystole, and Wolff-Parkinson-White syndrome have also been reported. ${ }^{28,34,51,96}$ To the best of our knowledge, only one pediatric case of mad honey intoxication has been reported; the patient experienced sinus bradycardia. ${ }^{97}$ Also, one pediatric case of grayanotoxin intoxication mediated by Rhododendron simsii was reported..$^{98}$ Table 5 shows cases (more than 2 patients and after 2004) reporting signs and symptoms of rhythm disorders including sinus bradycardia, brady-arrhythmia, atrial fibrillation, nodal rhythm, Wolff-Parkinson-White syndrome, AV block, and second heart block.

Apart from the aforementioned cardiovascular effects and rhythm disorders, the patient might present gastrointestinal, respiratory, and some neurological symptoms including dizziness, diaphoresis, light-headedness, impaired consciousness or mental confusion, perioral paraesthesia, blurred vision, diplopia, vomiting, nausea, chest pain, fatigue, and generalized weakness. ${ }^{53,55,70,75,86,95,98}$ Excessive salivation and convulsions due to depolarized neurons (central nervous system) may also be presented by some patients. ${ }^{51,96}$

Studies on animals revealed some effects in the form of respiratory depression, decreased blood lipid and sugar levels, renal toxicity (proteinuria and haematuria), altered antioxidant enzyme system, induced stress (lipid peroxidation in terms of increase in the level of MDA), liver toxicity (focal necrosis, congestion, dilation of hepatic central vein, transaminitis, infiltration of inflammatory cells in parenchyma, and hepatic portal triad), reduced amplitude and frequency of epileptiform spike, convulsion, and seizures. ${ }^{32,57,99-103}$ However, there is no report of these effects in humans. Türkmen et al. ${ }^{104}$ observed that injecting $200 \mu \mathrm{g} \mathrm{kg}^{-1}$ mad honey (grayanotoxin III) lowered the blood pressure of rats significantly; also, a further decrease in the blood pressure and heart rate was observed for rats injected with $400 \mu \mathrm{g} \mathrm{kg}{ }^{-1}$ and $800 \mu \mathrm{g} \mathrm{kg}{ }^{-1}$ mad honey as compared to the observations for rats in the control group. Their study on rats clearly elucidated the pathways of hypotension and bradycardia, which are frequently observed in mad honey-intoxicated/poisoned humans.

\section{Diagnosis and prognosis of mad honey poisoning/ intoxication}

Mad honey intoxication is diagnosed clinically, and it is suspected in patients having no record of earlier heart diseases and 
Table 4 Cases reported regarding mad honey intoxication and reported cardiac signs and symptoms (more than two patients)

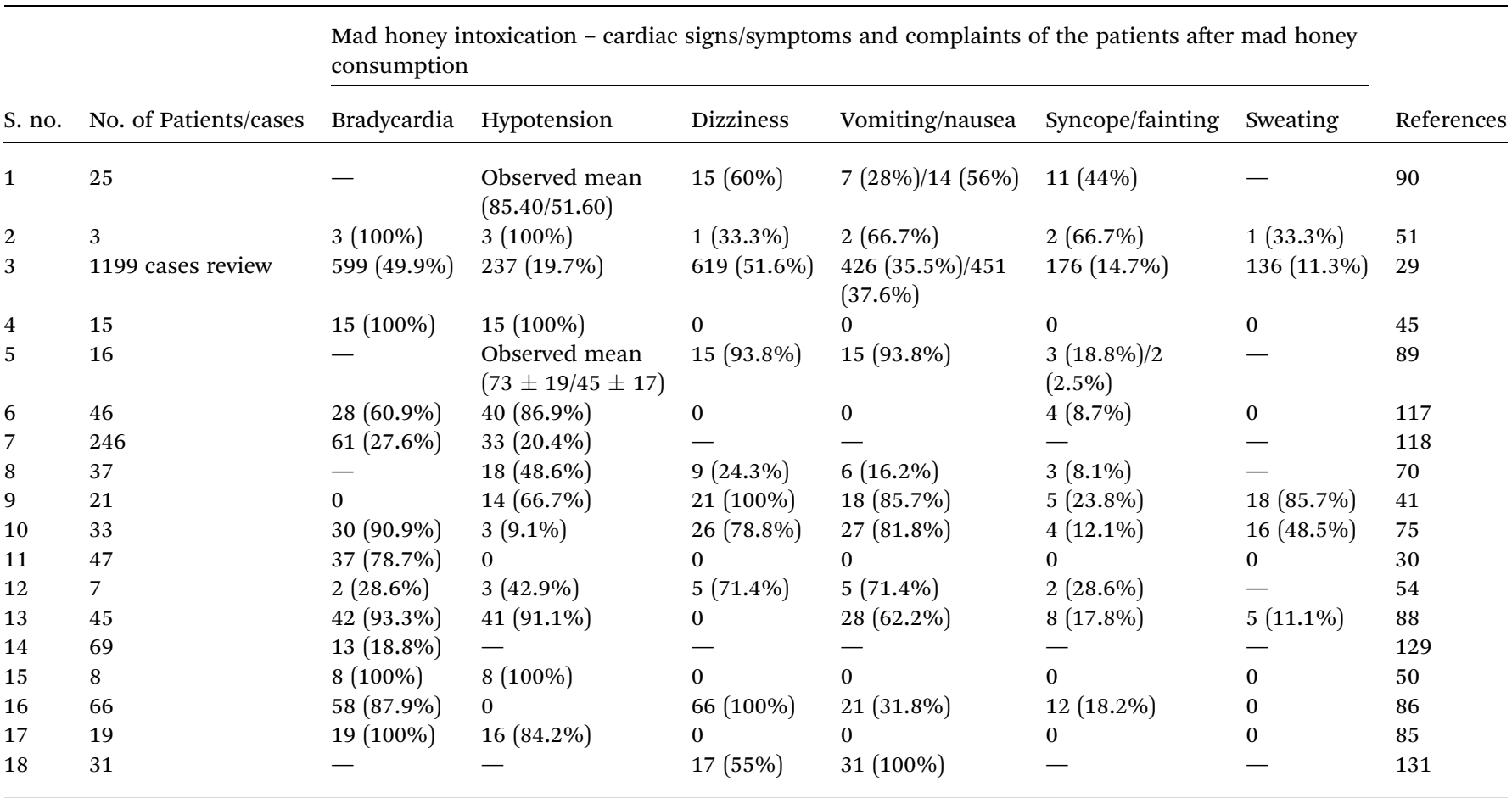

presenting bradycardia, hypotension, nausea, vomiting, and syncope after consumption of honey. ${ }^{53}$ The symptoms of grayanotoxin intoxication are similar to those of mad honey intoxication after the consumption of leaves, roots, bark, and flowers of the plants of the Ericaceae family, mainly Rhododendron species. However, intoxication from the consumption of commercial honey is very rare, as the honey is collected from various sources, and the toxin is diluted across all samples if it is present in any sample.

There is no routine test available to reveal and measure the level of grayanotoxin in the blood of the patient; however, it is sufficient to diagnose mad honey intoxication through clinical findings, such as the history of honey consumption before the appearance of the symptoms, especially in those areas where mad honey intoxication/poisoning is common. The more common symptoms of mad honey poisoning observed in patients admitted to the emergency departments are hypotension, bradycardia, syncope, stupor, vertigo, nausea, vomiting, extremity paraesthesia, dizziness, blurred vision, diplopia, lightheadedness, sweating, hypersalivation, altered mental state, unconsciousness, and general weakness. ${ }^{51,55}$

There is no commercially available laboratory test for diagnosing mad honey intoxication; however, for grayanotoxin detection in a honey sample, thin layer chromatography and

Table 5 Cases reported regarding mad honey intoxication/poisoning and reported rhythm disorders (more than 2 patients)

\begin{tabular}{|c|c|c|c|c|c|c|c|c|c|}
\hline \multirow[b]{2}{*}{ S. no. } & \multirow[b]{2}{*}{$\begin{array}{l}\text { No. of } \\
\text { patients/cases }\end{array}$} & \multicolumn{7}{|c|}{ Mad honey intoxication - rhythmic disorders (ECG findings) } & \multirow[b]{2}{*}{ References } \\
\hline & & $\begin{array}{l}\text { Sinus } \\
\text { bradycardia }\end{array}$ & $\begin{array}{l}\text { Brady- } \\
\text { arrhythmia }\end{array}$ & $\begin{array}{l}\text { Atrial } \\
\text { fibrillation }\end{array}$ & $\begin{array}{l}\text { Junctional } \\
\text { /nodal rhythm }\end{array}$ & $\begin{array}{l}\text { Wolff-Parkinson- } \\
\text { White syndrome }\end{array}$ & AV block & $\begin{array}{l}\text { Second } \\
\text { heart block }\end{array}$ & \\
\hline 1 & $\begin{array}{l}1199 \\
\text { cases review }\end{array}$ & $954(79.5 \%)$ & $46(3.83 \%)$ & $104(8.7 \%)$ & $\begin{array}{l}53(4.4 \%) / 138 \\
(11.6 \%)\end{array}$ & $1(0.09 \%)$ & $370(30.8 \%)$ & - & 29 \\
\hline 2 & 3 & $3(100 \%)$ & 0 & 0 & 0 & 0 & 0 & 0 & 51 \\
\hline \multirow[t]{2}{*}{3} & 15 & $8(53.3 \%)$ & 0 & $1(6.6 \%)$ & $4(26.7 \%)$ & 0 & $2(13.3 \%)$ & 0 & 45 \\
\hline & 16 & $9(56.3 \%)$ & - & $2(12.5 \%)$ & $3(18.8 \%)$ & - & $2(12.5 \%)$ & - & 89 \\
\hline 4 & 46 & $28(60.9 \%)$ & 0 & 0 & 0 & 0 & $1(2.2 \%)$ & 0 & 97 \\
\hline 5 & 37 & $17(45.9 \%)$ & - & $5(13.5 \%)$ & - & - & $5(13.5 \%)$ & - & 70 \\
\hline 6 & 21 & $7(33.3 \%)$ & 0 & $1(4.8 \%)$ & $3(14.3 \%)$ & 0 & 0 & 0 & 41 \\
\hline 7 & 33 & $30(90.9 \%)$ & 0 & 0 & 0 & 0 & 0 & 0 & 75 \\
\hline 8 & 47 & 0 & 0 & 0 & 0 & 0 & $1(2.1 \%)$ & 0 & 30 \\
\hline 9 & 45 & $38(84.4 \%)$ & 0 & 0 & $2(4.4 \%)$ & 0 & 0 & $2(4.4 \%)$ & 88 \\
\hline 10 & 69 & 37 (54\%) & & & $8(11.6 \%)$ & $1(1.45 \%)$ & $7(8.7 \%)$ & & 129 \\
\hline 11 & 8 & $4(50 \%)$ & 0 & 0 & $3(37.5 \%)$ & 0 & $1(12.5 \%)$ & 0 & 50 \\
\hline 12 & 19 & 0 & 0 & 0 & 0 & 0 & $4(21.1 \%)$ & 0 & 85 \\
\hline
\end{tabular}


paper electrophoresis are adapted as standard procedures. ${ }^{105,106}$ Gas and gas-liquid chromatographies can also be used because grayanotoxin has low vapor pressure and is a heat labile compound. Other possible techniques for the detection of grayanotoxin are HPLC, LCMS/MS, nuclear magnetic resonance, and infrared-based technologies..$^{64,90,107-110,130}$ For corroborative evidence, pollen grains from Rhododendron (its flowers are rich in grayanotoxin) can be investigated occasionally in honey samples.

Cardiac ischemia and rhythm abnormalities should be checked by ECG. Ischemic change is commonly observed in patients presenting chest pressure. Acute coronary syndrome, which is normal in mad honey intoxication, can be ruled out with a coronary angiogram. Organophosphate poisoning has similar cholinergic excess presentation as compared to mad honey poisoning, and it can be ruled out by estimating the level of cholinesterase enzyme in the serum as in mad honey poisoning, the level of the enzyme is not affected. ${ }^{111}$

Although the presented symptoms seem to be lifethreatening, the prognosis is very good for mad honey intoxication, and almost all patients respond to the provided treatment. ${ }^{67}$ There is no case reporting fatality due to mad honey intoxication in the recent medical literature. ${ }^{40}$ However, Zhang et al. ${ }^{131}$ reported the death of 8 out of 31 patients $(25.8 \%)$ in Lanping County, Southeast China. They reported a total of 31 cases, of which 14 were males and 17 were females; 11 patients consumed wild honey, whereas 20 consumed farmed honey, and the mortality rates were $18.2 \%$ and $30.0 \%$, respectively. The average amount of honey consumed was $100 \pm 70 \mathrm{~g}$, and the symptoms appeared after a median time of $29 \mathrm{~h}$ after ingestion of honey containing toxins from T. hypoglaucum. A few cases of fatalities were also reported in the 1800 s, when normal saline and atropine were not available. ${ }^{126}$

\section{Treatment}

The signs and symptoms of mad honey poisoning, if not treated, can be observed for a day. ${ }^{28,41,78}$ The recovery of the normal mental status is gradual, and it might take several days for the patients to recover completely and be free of all the vital signs. ${ }^{30}$ Symptomatic treatment is adopted in the cases of mad honey intoxication/poisoning. Dizziness and mild hypotension are treated with saline infusion, and atropine is preferred in case of severe hypotension and bradycardia. The normal required dose is $0.5-2 \mathrm{mg}^{30,55}$ The antiplatelet therapy is not suggested, even in patients with acute coronary syndrome, due to the decreased supply of oxygen to their heart (pathophysiological mechanism), after hypotension or bradycardia. ${ }^{51,126}$ In any unusual case where the patient is not responding to normal saline and atropine, temporary cardiac pacing is used for washing out the toxins of the system, and it is suggested till all the toxins are washed out. ${ }^{40}$

If saline infusion and atropine are not adequate, then epinephrine or dopamine infusion and transvenous pacing are suggested. The use of a temporary transvenous pacemaker is reported in 3 patients till date, due to asystole and complete heart block. ${ }^{30,40,112}$ Gunduz et al. ${ }^{30}$ did not observe any difference in morbidity and mortality between patients admitted to hospital and patients briefly observed in the emergency room. They recommend that, in the case of mad honey intoxication/ poisoning, six hours monitoring of the patient for stabilization is sufficient, and hospital admission is not required. Sohn et al. ${ }^{45}$ observed that all patients recovered after treatment with intravenous saline infusion or after normal saline infusion with atropine sulfate $(0.5-2 \mathrm{mg})$ simultaneously. The pulse rate and blood pressure of patients were within normal limits after the aforementioned treatment within $24 \mathrm{~h}$.

\section{Conclusion}

Mad honey intoxication is caused by the ingestion of grayanotoxin extracted from the leaves and flowers (nectars and pollens) of Rhododendron plant species by honey bees. The signs and symptoms of mad honey intoxication/poisoning are reported to be the same around the globe including Turkey, China, Republic of Korea, Nepal, Philippines, etc. Mad honey intoxication/poisoning should be taken into consideration in previously healthy patients presenting bradycardia, various bradydysrhythmias, and unexplained hypotension after obtaining a dietary history of mad honey ingestion.

The symptoms of mad honey intoxication last for a day, due to rapid metabolism and excretion of grayanotoxins. The signs and symptoms of mad honey intoxication/poisoning may seem life-threatening; however, no fatality has been reported in recent medical literature. For treating mad honey intoxication/ poisoning, symptomatic treatment and close surveillance are carried out. To ensure recovery, cardiac monitoring with supportive care, intravenous infusion of atropine sulfate, and intravenous saline infusion are used; in case of complete atrioventricular block, a temporary pacemaker is used.

\section{Conflicts of interest}

The authors report no conflicts of interest in this work.

\section{Acknowledgements}

The author S. Ullah has been supported by the Chinese Scholarship Council for his PhD study (CSC No. 2016GXX169). TA Saleh would like to acknowledge the support and funding provided by King Fahd University of Petroleum \& Minerals (KFUPM) through Project No. IN161011 and No. IN131053 under the Deanship of Research.

\section{References}

1 P. Missio da Silva, C. Gauche, L. V. Gonzaga, A. C. O. Costa and R. Fett, Honey: Chemical compositon, stability and authenticity, Food Chem., 2016, 196, 309-323.

2 O. O. Erejuwa, S. A. Sulaiman and M. S. Ab Wahad, Effects of honey and its mechanisms of action on the development and progression of cancer, Molecules, 2014, 19, 2497-2522.

3 P. V. Rao, K. T. Krishnan, N. Salleh and S. H. Gan, Biological and therapeutic effects of honey produced by honey bees 
and stingless bees: a comprehensive review, Brazilian Journal of Pharmacognosy, 2016, 26, 657-664.

4 P. McLoone, M. Warnock and L. Fyfe, Honey: A realistic antimicrobial for disorders of the skin, J. Microbiol., Immunol. Infect., 2016, 49, 161-167.

5 V. R. Pasupuleti, L. Sammugam, N. Ramesh and S. H. Gan, Honey, propolis, and royal jelly: a comprehensive review of their biological actions and health benefits, Oxid. Med. Cell. Longevity, 2017, 1259510, DOI: 10.1155/2017/1259510.

6 S. Bogdanov, T. Jurendic, R. Sieber and P. Gallmann, Honey for nutrition and health: a review, J. Am. Coll. Nutr., 2008, 27, 677-689.

7 T. Eteraf-Oskouei and M. Najaf, Traditional and modern uses of natural honey in human diseases: a review, Iran. J. Basic Med. Sci., 2013, 16, 731-742.

8 M. Fukuda, K. Kobayashi, Y. Hirono, M. Miyagawa, T. Ishida, et al. Jungle honey enhances immune function and antitumor activity, J. Evidence-Based Complementary Altern. Med., 2011, 11, 8.

9 N. Noor, R. A. Sarfraz, S. Ali and M. Shahid, Antitumor and antioxidant potential of some selected Pakistani honeys, Food Chem., 2014, 143, 362-366.

10 M. Kassim, M. Achoui, M. R. Mustafa, M. A. Mohd and K. M. Yusoff, Ellagic acid, phenolic acids, and flavonoids in Malaysian honey extracts demonstrate in vitro antiinflammatory activity, Nutr. Res., 2010, 30, 650-659.

11 J.-R. Liu, Y.-L. Ye, T.-Y. Lin, Y.-W. Wang and C.-C. Peng, Effect of floral sources on the antioxidant, antimicrobial, and anti-inflammatory activities of honeys in Taiwan, Food Chem., 2013, 139, 938-943.

12 M. Morais, L. Moreira, X. Feas and L. M. Estevinho, Honeybee-collected pollen from five Portuguese Natural Parks: Palynological origin, phenolic content, antioxidant properties and antimicrobial activity, Food Chem. Toxicol., 2011, 49, 1096-1101.

13 A. Shahzad and R. J. Cohrs, In vitro antiviral activity of honey against varicella zoster virus (VZV): A translational medicine study for potential remedy for shingles, Transl. Biomed., 2012, 3, 2.

14 M. A. Hashemipour, Z. Tavakolineghad, S. A. Arabzadeh, Z. Iranmanesh and S. A. Nassab, Antiviral activities of Honey, Royal Jelly, and Acyclovir against HSV-1, Wounds, 2014, 26, 47-54.

15 K. Watanabe, R. Rahmasari, A. Matsunaga, T. Haruyama and N. Kobayashi, Anti-influenza viral effects of honey in vitro: potent high activity of manuka honey, Arch. Med. Res., 2014, 45, 359-365.

16 A. T. Khalil, I. Khan, K. Ahmad, Y. A. Khan, J. Khan and Z. K. Shinwari, Antibacterial activity of honey in northwest Pakistan against select human pathogens, J. Tradit. Chin. Med., 2014, 34, 86-89.

17 A. A. M. Al-Nahari, S. B. Almasaudi, E. M. A. El-Ghany, E. Barbour, S. K. Al Jaouni and S. Harakeh, Antimicrobial activities of Saudi honey against Pseudomonas aeruginosa, Saudi J. Biol. Sci., 2015, 22, 521-525.

18 S. M. Osés, A. Pascual-Maté, D. de la Fuente, A. de Pablo, M. A. Fernández-Muiño and M. T. Sancho, Comparison of methods to determine antibacterial activity of honeys against Staphylococcus aureus, NJAS - Wageningen Journal of Life Sciences, 2016, 78, 29-33.

19 S. B. Almasaudi, A. A. M. Al-Nahari, E. S. M. A. El-Ghany, E. Barbour, S. M. Al Muhayawi, S. Al-Jaouni, E. Azhar, M. Qari, Y. A. Qari and S. Harakeh, Antimicrobial effect of different types of honey on Staphylococcus aureus, Saudi J. Biol. Sci., 2017, 24, 1255-1261.

20 H. T. Tan, R. A. Rahman, S. H. Gan, A. S. Halim, S. A. Hassan, et al. The antibacterial properties of Malaysian tualang honey against wound and enteric microorganisms in comparison to manuka honey, $B M C$ Complementary Altern. Med., 2009, 9, 34.

21 M. K. Rakha, Z. I. Nabil and A. A. Hussein, Cardioactive and vasoactive effects of natural wild honey against cardiac malperformance induced by hyperadrenergic activity, $J$. Med. Food, 2008, 11, 91-98.

22 O. O. Erejuwa, S. A. Sulaiman, M. Wahab, K. Sirajudeen, M. Salleh, et al. Hepatoprotective effect of tualang honey supplementation in streptozotocin-induced diabetic rats, Int. J. Appl. Res. Nat. Prod., 2012a, 4, 37-41.

23 O. O. Erejuwa, S. A. Sulaiman and M. S. A. Wahab, Honey A novel antidiabetic agent, Int. J. Biol. Sci., 2012b, 8, 913934.

24 S. A. Meo, M. J. Ansari, K. Sattar, H. Chaudhary, W. Hajjar and S. Alasiri, Honey and diabetes mellitus: obstacles and challenges - road to be repaired, Saudi J. Biol. Sci., 2017, 24, 1030-1033.

25 E. O. Omotayo, S. Gurtu, S. A. Sulaiman, M. S. Ab Wahab, K. N. S. Sirajudeen, et al. Hypoglycemic and antioxidant effects of honey supplementation in streptozotocin induced diabetic rats, Int. J. Vitam. Nutr. Res., 2010, 80, 74-82.

26 V. Patricia, O. Vargas, T. López and F. M. Valle, Meliponini biodiversity and medicinal uses of pot-honey from El Oro province in Ecuador, Emir. J. Food Agric., 2015, 27, 502-506.

27 E. O. Omotayo, S. A. Siti, M. S. Ab Wahab, K. N. S. Sirajudeen, M. S. M. Salleh, et al. Honey Supplementation in Spontaneously Hypertensive Rats Elicits Antihypertensive Effect via Amelioration of Renal Oxidative Stress, Oxid. Med. Cell. Longevity, 2012, 14, 374037.

28 M. Sayin, S. Dogan, M. Aydin and T. Karabag, Extreme QT interval prolongation caused by mad honey consumption, Can. J. Cardiol., 2011, 27, e17-e19.

29 S. Salici and A. T. Atayoglu, Mad honey intoxication: A systematic review on the 1199 cases, Food Chem. Toxicol., 2015, 86, 282-290.

30 A. Gunduz, E. S. Meriçé, A. Baydin, M. Topbaş, H. Uzun, S. Turedi and A. Kalkan, Does mad honey poisoning require hospital admission?, Am. J. Emerg. Med., 2009, 27, 424-427.

31 T. W. Weiss, P. Smetana, M. Nurnberg and K. Huber, The honey man-second degree heart block after honey intoxication, Int. J. Cardiol., 2010, 142, e6-e7.

32 S. Sibel, Y. M. Enis, S. Huseyin, A. A. TImucin and O. Duran, Analysis of grayanotoxin in Rhododendron honey and effect 
on antioxidant parameters in rats, J. Ethnopharmacol., 2014, 156, 155-161.

33 A. B. Kurtoglu, R. Yavuz and G. A. Evrendilek, Characterisation and fate of grayanotoxins in mad honey produced from Rhodendron ponticum nectar, Food Chem., 2014, 161, 47-52.

34 A. Gunduz, I. Durmus, S. Turedi, I. Nuhoglu and S. Ozturk, Mad honey poisoning-related asystole, Emerg. Med. J., 2007, 24, 592-593.

35 I. Koca and A. F. Koca, Poisoning by mad honey: A brief review, Food Chem. Toxicol., 2007, 45, 1315-1318.

36 A. Gunduz, O. Tatll and S. Turedi, Mad honey poisoning from the past to the present, Turk. J. Emerg. Med., 2008, 8, 46-49.

37 K. E. Cagli, O. Tufekcioglu, N. Sen, D. Aras, S. Topaloglu, N. Basar, et al. Atrioventricular block induced by madhoney intoxication, Texas Heart Institute Journal, 2009, 36, 342-344.

38 F. Aliyev, C. Türkoglu, C. Celiker, I. Firatli, G. Alici, et al. Chronic mad honey intoxication syndrome: a new form of an old disease?, Europace, 2009, 11, 954-956.

39 P. Eller and K. Hochegger, Honey intoxication and the Bezold-Jarisch reflex, Int. J. Cardiol., 2010, 144, 251.

$40 \mathrm{H}$. Yorgun, A. Ulgen and K. Aytemir, A rare cause of junctional rhythm causing syncope; mad honey intoxication, J. Emerg. Med., 2010, 39, 656-658.

$41 \mathrm{H}$. Demir, A. Denizbasi and O. Onur, Mad honey intoxication: A case series of 21 patients, ISRN Toxicol., 2011, 11, 3 .

42 C. Lennerz, C. Jilek, V. Semmler, I. Deisenhofer and C. Kolb, Sinus arrest from mad honey disease, Ann. Intern. Med., 2012, 157, 755-756.

43 M. R. Sayin, T. Karabag, S. M. Dogan, I. Akpinar and M. Aydin, Transient ST segment elevation and left bundle branch block caused by mad-honey poisoning, Wien. Klin. Wochenschr., 2012, 124, 278-281.

44 S. P. L. Chen, Y. H. Lam, V. C. H. Ng, F. L. Lau, Y. C. Sze, W. T. Chan and T. W. L. Mak, Mad honey poisoning mimicking acute myocardial infarction, Hong Kong Med. J., 2013, 19, 354-356.

45 C. H. Sohn, D. W. Seo, S. M. Ryoo, J. H. Lee, W. Y. Kim, K. S. Lim and B. J. Oh, Clinical characteristics and outcomes of patients with grayanotoxin poisoning after the ingestion of mad honey from Nepal, Intern. Emerg. Med., 2014, 9, 207-211.

46 R. Koda, M. Honma, K. Suzuki, A. Kasai, T. Takeda, I. Narita and K. Yoshida, Hypotension and bradycardia caused by the Inadvertent ingestion of Rhododendron japonicum, Intern. Med., 2015, 55, 839-842.

47 B. Shrestha and P. Paudel, A case report on mad (wild) honey intoxication, Journal of Chitwan Medical College, 2015, 5, 40-41.

48 Mok, D. Hong Kong man, 61, suffers from rare 'mad honey' poisoning after eating spoonful from Nepal. Health and Environment. 2017. Available at: http:/www.scmp.com/ news/hong-kong/health-environment/article/2065249/ hong-kong-man-61-suffers-rare-poisoning-after, accessed on: January $12^{\text {th }}, 2018$.

49 E. Dilber, M. Kalyoncu, N. Yaris and A. Ökten, A Case of Mad Honey Poisoning Presenting with Convulsion: Intoxication Instead of Alternative Therapy, Turk. J. Med. Sci., 2002, 32, 361-362.

50 A. Gunduz, S. Turedi, H. Uzun and M. Topbas, Mad honey poisoning, Am. J. Emerg. Med., 2006, 24, 595-598.

51 A. Aygun, H. S. Vuran, N. Aksut, Y. Karaca, A. Gunduz and S. Turedi, Mad honey poisoning-related hypothermia: A case series, J. Emerg. Med., 2016, 50, 51-54.

52 T. F. Lue and A. Wood, Erectile dysfunction, N. Engl. J. Med., 2000, 342, 1802-1812.

53 A. Demircan, A. Keles, F. Bildik, G. Aygencel, N. O. Dogan and H. F. Gomez, Mad honey sex: Therapeutic misadventures from an ancient biological weapon, Ann. Emerg. Med., 2009, 54, 824-829.

54 P. Shrestha, R. Vaidya and K. Sherpa, Mad honey poisoning: a rare case report of seven cases, Nepal Med. Coll. J., 2009, 11, 212-213.

55 N. A. Bayram, T. Keles, T. Durmaz, S. Dogan and E. Bozkurt, A rare cause of atrial fibrillation: mad honey intoxication, $J$. Emerg. Med., 2012, 43, e389-e391.

56 R. Popescu and B. Kapp, The genus Rhododendron: an ethnopharmacological and toxicological review, $J$. Ethnopharmacol., 2013, 147, 42-62.

57 N. Oztasan, K. Altınkaynak, F. Akçay, F. Göçer and S. Dane, Effects of mad honey on blood glucose and lipid levels in rats with streptozotocin-induced diabetes, Turk. J. Vet. Anim. Sci., 2005, 29, 1093-1096.

58 T. F. Prakash, D. S. Snehal, R. S. Uday, V. Surendra, D. Goli, P. Stamina and D. Kotresha, Hepatoprotective activity of leaves of Rhododendron arboreum in $\mathrm{CCl}_{4}$ induced hepatotoxicity in rats, J. Med. Plants Res., 2008, 2, 315-320.

59 N. Erdemoglu, E. K. Akkol, E. Yesilada and I. Calis, Bioassay-guided isolation of anti-inflammatory and antinociceptive principles from a folk remedy, Rhododendron ponticum L. leaves, J. Ethnopharmacol., 2008, 119, 172-178.

60 Ö. Ertürk, F. P. Karaka, D. Pehlivan and N. Nas, The antibacterial and antifungal effects of Rhododendron derived mad honey and extracts of four Rhododendron species, Turkish J. Biol., 2009, 33, 151-158.

61 X. Jing, Z. Zhonghua, L. Jianshe and W. Yang, The effect of root of Rhododendron on the activation of NF- $\kappa$ B in a chronic glomerulonephritis rat model, Journal of Nanjing Medical University, 2009, 23, 73.

62 S. Silici, O. Sagdıc and L. Ekici, Total phenolic content, antiradical, antioxidant and antimicrobial activities of Rhododendron honeys, Food Chem., 2010, 121, 238-243.

63 M. Yarlioglues, M. Akpek, I. Ardic, D. Elcik, O. Sahin and M. G. Kaya, Mad-honey sexual activity and acute inferior myocardial infarctions in a married couple, Texas Heart Institute Journal, 2011, 38, 577-580.

64 S. Silici, K. Sarioglu, M. Dogan and K. Karaman, HPLC-DAD analysis to identify the phenolic profile of Rhodendron 
honeys collected from different regions in Turkey, Int. J. Food Prop., 2014, 17, 1126-1135.

65 S. Silici and K. Karaman, Chemometric Approaches for the Characterization of Turkish Rhododendron and Honeydew Honeys Depending on Amino Acid Composition, J. Liq. Chromatogr. Relat. Technol., 2014, 37, 864-877.

66 S. Buratti, S. Benedetti and M. S. Cosio, Evaluation of the Antioxidant Power of Honey, Propolis and Royal Jelly by Amperometric Flow Injection Analysis, Talanta, 2007, 71, 1387-1392.

67 Y. K. Choo, H. Y. Kang and S. H. Lim, Cardiac problems in madhoney intoxication, Circ. J., 2008, 72, 1210-1211.

68 J. Wong, E. Youde, B. Dickinson and M. Hale, Report of the Rhododendron feasibility study, School of Agricultural and Forest Sciences, University of Whales, Bangor, UK, 2002, Available at: https:/www.wildresources.co.uk/reports/ rhodo_eng.pdf, Accessed March 4th, 2018.

69 A. Gunduz, S. Turedi and H. Oksuz, The honey, the poison, the weapon, Wilderness Environ. Med., 2011, 22, 182-184.

70 A. S. D. Akca and F. O. Kahveci, An indispensable toxin known for 2500 years: victims of mad honey, Turk. J. Med. Sci., 2012, 42, 1499-1504.

71 T. Yuki, K. Yamaoka, M. Yakehiro and I. Seyama, Statedependent action of grayanotoxin $\mathrm{I}$ on $\mathrm{Na}^{+}$channels in frog ventricular myoctes, J. Physiol., 2001, 534, 777-790.

72 H. Maejima, E. Kinoshita, I. Seyama and K. Yamaoka, Distinct sites regulating grayanotoxin binding and unbinding to D4S6 of $\mathrm{Na}(\mathrm{v}) 1.4$ sodium channel as revealed by improved estimation of toxin sensitivity, $J$. Biol. Chem., 2003, 278, 9464-9471.

73 W. A. Catterall, A. L. Goldin and S. G. Waxman, International Union of Pharmacology. XLVII. Nomenclature and structure-function relationships of voltage-gated sodium channels, Pharmacol. Rev., 2008, 57, 397-409.

74 I. Seyama, K. Yamaoka, M. Yakehiro, Y. Yoshioka and K. Morihara, Is the site of action of grayanotoxin in the sodium channel gating of squid axon?, Jpn. J. Physiol., 1985, 35, 401-410.

75 M. Bostan, H. Bostan, A. O. Kaya, O. Bilir, O. Satiroglu, H. Kazdal, Z. Karadag and E. Bozkurt, Clinical events in mad honey poisoning: a single centre experience, Bull. Environ. Contam. Toxicol., 2010, 84, 19-22.

76 T. Kimura, K. Yamaoka, E. Kinoshita, H. Maejima, T. Yuki, et al. Novel site on sodium channel alpha-subunit responsible for the differential sensitivity of grayanotoxin in skeletal and cardiac muscle, Mol. Pharmacol., 2001, 60, 865-872.

77 F. Onat, B. C. Yegen, R. Lawrence, A. Oktay and S. Oktay, Site of action grayanotoxins in mad honey in rats, J. Appl. Toxicol., 1991b, 11, 199-291.

78 K. Ergun, O. Tufekcioglu, D. Aras, S. Korkmaz and S. Pehlivan, A rare cause of atrioventricular block: Mad honey intoxication, Int. J. Cardiol., 2005, 99, 347-348.

79 F. Y. Onat, B. C. Yegen, R. Lawrence, A. Oktay and S. Oktay, Mad honey poisoning in man and rat, Rev. Environ. Health, 1991a, 9, 3-9.
80 M. Asçioğlu and C. Ozesmi, Effects of grayanotoxin-I on threshold intensity and compound action potential of frog sciatic nerve, J. Physiol. Pharmacol., 1996, 47, 341-349.

$81 \mathrm{M}$. Nakao and I. Seyama, Effect of alpha-dihydrograyanotoxin-II on the electrical activity of the rabbit sinoatrial node, J. Physiol., 1984, 357, 79.

82 S. Kim, M. Shin, N. Akaike and C. Kim, Presynaptic effects of grayanotoxin III on excitatory and inhibitory nerve terminals in rate ventromedial hypothalamic neurons, NeuroToxicology, 2010, 31, 230-238.

83 B. S. Brown, T. Akera and T. M. Brody, Mechanism of grayanotoxin III induced aierpotentLals in feline cardiac Purkinje fbers, Eur. J. Pharmacol., 1981, 75, 271-281.

$84 \mathrm{H}$. Harissis and G. Mavrofridis, Mad honey in medicine from antiquity to the present day, Archives of Hellenic Medicine, 2013, 30, 730-733.

85 H. Ozhan, R. Akdemir, M. Yazici, H. Gündüz and S. Duran, Cardiac emergencies caused by honey ingestion: a single centre experience, Emerg. Med. J., 2004, 21, 742-744.

86 O. Yilmaz, M. Eser, A. Sahiner, L. Altintop and O. Yesildag, Hypotension, bradycardia and syncope caused by honey poisoning, Resuscitation, 2006, 68, 405-408.

87 E. Okuyan, A. Uslu and M. Ozan Levent, Cardiac effects of "mad honey": a case series, Clin. Toxicol., 2010, 48, 528532.

88 C. Kati, T. Yardan and H. Akdemir, Is there a relation between gender and the clinical course of mad honey poisoning?, Turk. J. Med. Sci., 2008, 38, 1-15.

89 S. Yaylaci, I. Kocayigit, E. Aydin, A. Osken, A. B. Genc, M. A. Cakar and A. Tamer, Clinical and laboratory findings in mad honey poisoning: A single center experience, Niger. J. Clin. Pract., 2014, 17, 589-593.

90 A. Aygun, A. Sahin, Y. Karaca, S. Turkmen, S. Turedi, S. Y. Ahn, S. Kim and A. Gunduz, Grayanotoxin levels in blood, urine and honey and their association with clinical status in patients with mad honey intoxication, Turk. J. Emerg. Med., 2018, 18, 29-33.

91 J. A. Campagna and C. Carter, Clinical relevance of the Bezold-Jarisch reflex, Anesthesiology, 2003, 98, 1250-1260.

92 S. Akinci, U. Arslan, K. Karakurt and A. Cengel, An unusual presentation of mad honey poisoning: acute myocardial infarction, Int. J. Cardiol., 2008, 129, e56-e58.

93 N. Yildirim, M. Aydin, F. Cam and O. Celik, Clinical presentation of non-ST-segment elevation myocardial infarction in the course of intoxication with mad honey, Am. J. Emerg. Med., 2008, 26, 108.

94 D. Dursunoglu, S. Gur and E. Semiz, A case with complete atrioventricular block related to mad honey intoxication, Ann. Emerg. Med., 2007, 50, 484-485.

95 O. Sogut, M. B. Sayhan, C. Mordeniz, M. T. Gokdemir and B. Al, Mad honey poisoning: a case report and review of the literature, Anatolian Journal of Clinical Investigation, 2009, 3, 100-102.

96 A. Gunduz, H. Bostan and S. Turedi, Wild flowers and mad honey, Wilderness Environ. Med., 2007, 18, 69-71. 
97 H. Uzun, I. Sari, C. Gunes and K. Kocabay, A child with bradycardia and hypotension related to mad honey intoxication, Turkish Archives of Pediatrics, 2013, 48, 53-54.

98 W. T. Poon, C. H. Ho, K. L. Kip, C. K. Lai, K. L. Cheung, R. Y. T. Sung, et al. Grayanotoxin poisoning from Rhododendron simsii in an infant, Hong Kong Med. J., 2008, 14, 405-407.

99 M. Aşçioğlu, Ç. Özesmi, P. Doğan and F. Öztürk, Effects of acute grayanotoxin-I administration on hepatic and renal functions in rats, Turk. J. Med. Sci., 2000, 30, 23-28.

100 T. Yuki, K. Yamaoka, M. Yakehiro and I. Seyama, Statedependent action of grayanotoxin $\mathrm{I}$ on $\mathrm{Na}^{+}$channels in frog ventricular myocytes, J. Physiol., 2001, 534, 777-790.

101 T. Terai, K. Osakabe, M. Katai, et al. Preparation of 9hydroxy grayanotoxin derivatives and their acute toxicity in mice, Chem. Pharm. Bull., 2003, 51, 351-353.

102 A. Gündüz, M. Aydin, M. Acka, S. Turkmen, S. Turedi, U. Eryigit, A. Cansu and M. Yildrim, Is grayanotoxin directly responsible for mad honey poisoning associated seizures, Turk. J. Med. Sci., 2012a, 42, 1086-1092.

103 P. Kuru, M. Torun, H. M. Halac, G. Temiz, E. Iskender, T. Karamahmutoglu, M. G. Idrizoglu and F. Y. Onat, Electroencephalographic and behavioral effects of intracerebroventricular or intraperitoneal injections of toxic honey extract in adult Wistar rats and GAERS, Neurol. Sci., 2014, 35, 1903-1908.

104 S. Türkmen, Ü. Karagöz, A. Gündüz, S. Türedi, M. Akça and M. Yildirim, The dose-dependent effect of grayanotoxin on the cardiovascular system, Turk. J. Med. Sci., 2013, 43, 700705.

$105 \mathrm{~J}$. W. White and M. L. Riethof, The composition of honey. 3. Detection of acetylandromedol in toxic honeys, Arch. Biochem. Biophys., 1959, 79, 165-167.

106 P. M. Scott, B. B. Coldwell and G. S. Wiberg, Grayanotoxins. Occurrence and analysis in honey and a comparison of toxicities in mice, Food Cosmet. Toxicol., 1971, 9, 179-184.

107 D. M. Holstege, B. Puschner and T. Le, Determination of grayanotoxins in biological samples by LC-MS/MS, $J$. Agric. Food Chem., 2001, 49, e1648-e1651.

108 H. E. Cho, S. Y. Ahn, D. W. Kim, et al. Development of a liquid chromatography tandem mass spectrometry method for the determination of grayanotoxins in rat blood and its application to toxicokinetic study, Biomed. Chromatogr., 2014, 28, 1624-1632.

109 H. Sahin, E. A. Turumtay and S. Kolayl, Determination of grayanotoxin-III in Turkish mad honey Samples by LCMS/MS, in 12th Asian Apicultural Association Conference at Antalya, 2014.

110 A. Aygun, A. Gunduz, S. Turedi, S. Turkmen, Y. Karaca, F. A. Ayaz, S. Y. Ahn and S. Kim, Examination using LCMS/MS determination of grayanotoxin levels in blood, urine, and honey consumed by patients presenting to the emergency department with mad honey intoxication and relations with clinical data: a preliminary study, Ann. Saudi Med., 2015, 35, 161-164.

111 A. Gunduz, A. Kalkan, S. Turedi, I. Durmus, S. Turkmen, et al. Pseudocholinesterase levels are not decreased in grayanotoxin (mad honey) poisoning in most patients, $J$. Emerg. Med., 2012, 43, 1008-1013.

112 Y. S. Choi, I. S. Jang, B. H. Kim, N. Y. Kwon, J. D. Kim, et al. A case of severe bradyarrhythmia after ingestion of Rhododendron brachycarpum, Korean Circ. J., 2002, 32, 268-270.

113 Y. Alsancak, S. Ali, M. Duran, M. Polat, S. Sivri and M. Bilge, A rare case of Kounis syndrome provoked by mad honey poisoning, International Journal of the Cardiovascular Academy, 2016, 2, 103-105.

114 T. Karabag, R. Sayin, N. Yavuz and Z. Aktop, Type 2 myocardial infarction after ingestion of mad honey in a patient with normal coronary arteries, Korean J. Intern. Med., 2015, 30, 540-542.

115 A. Dur, E. Sonmez, C. Civelek, K. A. Turkdogan, O. Sogut and M. A. Vatankulu, Mad honey intoxication mimicking acute coronary syndrome, J. Pak. Med. Assoc., 2014, 9, 1078-1080.

116 S. Yaylaci, O. Ayyildiz, E. Aydin, A. Osken, F. Karahalil, C. Varim, M. V. Demir, A. B. Genc, S. Sahinkus, Y. Can, I. Kocayigit and C. Bilir, Is there a difference in mad honey poisoning between geriatric and non-geriatric patient groups?, Eur. Rev. Med. Pharmacol. Sci., 2015, 19, 4647-4653.

117 H. Uzun, H. Narci, I. Tayfur, K. U. Karabulut and O. Karcioglu, Mad honey intoxication: what is wrong with the blood glucose? A study on 46 patients, Eur. Rev. Med. Pharmacol. Sci., 2013, 17, 2728-2731.

118 M. C. Sumerkan, E. E. Simsek, A. S. Mayda and M. A. Agirbasli, Epidemiological evaluation of mad-honey intoxication $-9^{\text {th }}$ Internatioanl Congress Update Cardiology \& Cardiovascular Surgery, Oral Presentations, Int. J. Cardiol., 2013, S1-S79.

119 A. Osken, S. Yaylaci, E. Aydin, I. Kocayigit, M. A. Cakar, A. Tamer and H. Gunduz, Slow ventricular response atrial fibrillation related to mad honey poisoning, J. Cardiovasc. Dis. Res., 2012, 3, 245-247.

120 H. Oguzturk, O. Ciftci, M. G. Turtay and S. Yumrutepe, Complete atrioventricular block caused by mad honey intoxication, Eur. Rev. Med. Pharmacol. Sci., 2012, 16, 1748-1750.

121 A. Kalkan, M. Gokce and M. E. Memetoglu, An unusual clinical state: atrial fibrillation due to mad-honey intoxication, Anatol. J. Cardiol., 2012, 12, 365-366.

122 A. Alp, S. Sappak, S. D. Sezer, C. Colak and M. Ozbakkaloglu, A rare cause of syncope among geriatric patients: mad honey intoxication, Turkish Journal of Geriatrics, 2012, 15, 115-117.

123 M. C. Sumerkan, M. Agirbasli, E. Altundag and S. Bulur, Mad-honey intoxication confirmed by pollen analysis, Clin. Toxicol., 2011, 49, 872-873.

124 A. Saritas, H. Kandis, D. Baltaci and I. Erdem, Paroxysmal atrial fibrillation and intermittent left bundle branch block: an unusual electrocardiographic presentation of mad honey poisoning, Clinics, 2011, 66, 1651-1653.

125 M. A. Cakar, Y. Can, M. B. Vatan, S. Demirtas, H. Gunduz and R. Akdemir, Atrial fibrillation induced by mad honey 
intoxication in a patient with Wolf-Parkinson-White syndrome, Clin. Toxicol., 2011, 49, 438-439.

126 R. Gami and P. Dhakal, Mad honey poisoning: A review, J. Clin. Toxicol., 2017, 7, 1-5.

127 X. Feás and M. L. Estevinho, A survey of the in vitro antifungal activity of heather (Erica sp.) organic honey, $J$. Med. Food, 2011, 14, 1284-1288.

128 D. G. Leach, Ancient curse of the rhododendron, Am. Horticulturist, 1972, 51, 20-29.

129 A. Gunduz, S. Turedi, R. M. Russell and F. A. Ayaz, Clinical review of grayanotoxin/mad honey poisoning past and present, Clin. Toxicol., 2008, 46, 437-442.

130 H. Sahin, E. A. Turumtay, O. Yildiz and S. Kolayli, Grayaotoxin-III detection and antioxidant activity of mad honey, Int. J. Food Prop., 2015, 18, 2665-2674.

131 Q. Zhang, X. Chen, S. Chen, Y. Ye, J. Luo, J. Li, S. Yu, H. Liu and Z. Liu, Fatal honey poisoning in southwest china: a case series of 31 cases, Southeast Asian J. Trop. Med. Public Health, 2017, 48, 189-196.

132 L. Dubey, A. Maskey and S. Regmi, Bradycardia and severe Hypotension caused by wild honey poisoning, Hellenic J. Cardiol., 2009, 50, 426-428.

133 A. M. Chancellor, A bitter-sweet tale from the land of milk and honey, Practical Neurology, 2013, 13, 185-187.

134 D. Mcnaughton, R. Goodwin, Reducing the threat tutu toxic tutu honey poses to the New Zealand beekeeping industry and consumers, Horticult. Food Res. Inst. New Zealand., 2008.

135 J. A. Lockwood, Six-legged soldiers: Using insects as weapons of war, Oxford University Press, New York, NY, 2008.

136 O. Tatli, The Black sea's poison; Mad honey, Journal of Analytical Research in Clinical Medicine, 2017, 5, 1-3. 